\title{
Hybridity and Ambivalence in Abe Tomoji's Shi no Hana
}

\author{
Shobichatul Aminah ${ }^{a^{*}}$, Ratna Juwita ${ }^{\mathrm{b}}$, Gratia Herdina Kumaseh ${ }^{\mathrm{c}}$ \\ ${ }_{\text {aniversitas Indonesia, Jl. Salemba Raya } 4 \text { Jakarta 10430, Indonesia }}$
b,c ${ }_{\text {Universitas Gadjah Mada, Jl. Nusantara } 1 \text { Bulaksumur Yogyakarta 55281, Indonesia }}$ \\ *Email: shobichatul@ui.ac.id
}

\begin{abstract}
This study aims to describe the hybridity and ambivalence in Abe Tomoji's novel, Shi no Hana, using postcolonial perspective. Shi no Hana describes the author's experience when he was a member of the Propaganda Troop on Java Island with a spatial setting in Batavia and Selekta (Malang). The time setting in this novel is during the Japanese occupation of Indonesia. This study examined the interaction between colonizers and colonized in the framework of Homi K. Bhabha's postcolonialism, which results in hybridity and ambivalence in the characters. In this study, the characters are identified and categorized based on their position as colonizer or colonized. In many kinds of research on postcolonial literary, the relationship between East and West, or between colonizer and colonized is seen as a hierarchical relationship where one party oppresses the other. However, this research does not merely look at the colonizer and colonized as a hierarchical relationship. This study found that hybridity and ambivalence can be seen through the depiction of characters who occupy the position of the colonizer and colonized at the same time.
\end{abstract}

Keywords: Japanese novel; Abe Tomoji; Post Colonialism; Homi K. Bhabha

\section{Introduction}

Abe Tomoji was a writer sent by the Japanese government to the south as a member of the propaganda force unit 16 . One month before the Pacific war, he received a letter from General Imamura Hitoshi as the Army Commander of the Army who made him a member of the Propaganda Force. He departed from Tokyo in January 1942 for Taiwan, then continued to the island of Java. In the Propaganda Troops, which will carry out military operations in Java, there were also writers such as Asano Akira, Ooki Atsuo, Kitahara Takeo, Takeda Rintaro and others. After experiencing a difficult journey because the allies attacked the ship, the Propaganda Force unit 16 successfully anchored in Batavia via Banten Bay. Then the Japanese army troops succeeded in crushing the Dutch army in Java on March 9, 1942. These propaganda troops then carried out military operations by providing research reports on cultural organizations and Dutch heritage books consisting of books of science and art. Abe Tomoji and several other writers were assigned to research books about Batavia and Nusantara. This task made him captivated by Javanese nature and culture, as well as Balinese dances. When carrying out military operations, Abe Tomoji, who tended to be pro-Independence, as voiced by Britain and America at that time, experienced a very dilemma. Under the pressure of the military commander, he suffered because what he did during the military operation wounded a sense of humanism in his heart.

Based on this experience, after the war, Abe Tomoji wrote a serial novel entitled Jawa no Mono which consists of 10 series. Shi no Hana written in 1946 was the first Jawa no Mono series (Kimura in Tomoji, 2009: iv). Shi no Hana described Abe Tomoji's experience when he was a member of the Propaganda Force on Java Island with a spatial setting in Batavia and Selekta (Malang). The time setting in the novel is during the Japanese occupation in Indonesia. Although the time setting of the novel is the wartime, not much war-related 
diction appears in the text. Here Abe Tomoji saw the war from a different perspective. War was not a story about humans from different nations dealing with carrying weapons, but about nations dealing with different nations, not to attack, but to understand each other.

Research on Shi no Hana by Abe Tomoji has been conducted by Yovinza Bethvine S from Surabaya State University (Bethvine, 2005). In her research, Yovinza discussed the generosity and sympathy of the character Kibi. Research on Shi no Hana with a theoretical framework of postcolonialism was conducted by Gita Frasiska from the Universitas Indonesia (Frasiska, 2013). In her thesis, Gita Frasiska discussed the orientalism discourse that appears in the novel using the postcolonial theory framework of Edward Said. Likewise, Irvina Restu Handayani discussed Humanism in Shi no Hana and Tsumi no $H i$ by Abe Tomoji on the framework of orientalism studies (Handayani, 2018).

In many kinds of research on postcolonial literary, the relationship between East and West, or between colonizer and colonized is seen as a hierarchical relationship where one party oppresses the other. However, this research does not merely look at the colonizer and colonized as a hierarchical relationship. This study found that hybridity and ambivalence can be seen through the depiction of characters who occupy the position of the colonizer and colonized at the same time. The ambivalence, according to Homi K. Bhabha, also be seen as a narrative strategy and an apparatus of power.

\section{Methods}

This study discussed the interaction between the colonizers and colonized in the framework of Homi K. Bhabha's postcolonialism, which resulted in the hybridity and ambivalence of the characters in Abe Tomoji's Shi no Hana. This research does not merely look at the colonizer and colonized as a hierarchical relationship where one party oppresses the other, and views one party as "us" and the other as "other". This study uses figures, events, space and time settings as units of analysis to see the interactions between elements in the text and to examine the hybridity and ambivalence that appear in the text.

In this study, the characters are identified and categorized based on their position as colonizer or colonized. According to the theory of postcolonialism, the colonizer is West, while the colonized is East. The colonizer-colonized's interaction can be seen from the relationship between the characters, the depiction of events, and the time and space setting.

\subsection{Post Colonial Theory in Literature}

Post Colonial literary theory examines colonial literature, primarily focusing on the social discourse between colonizers and colonizers, which are the background of literary works. Postcolonial literary writers deal with traditional (colonial) discourse either by modifying or subverting it or both. The anti-colonialism narrative sees the natives of the colony as victims, not enemies. In general, postcolonial literature is using the colonizer language but in a different way. In this case, the colonizer language, which is usually used to oppress the colonized, is used for the opposite thing, namely challenging the colonizer. Postcolonial literature challenge narrative colonizers who tell their superiority, by presenting a meta-narrative that warns how narrative colonizers are always told only from their point of view, and tells about the impact of colonialization, and attacking colonialism discourse which contains a collection of narratives, statements and opinions relating to the colonized society from the perspective of the colonizer (Said: 1978).

Postcolonial literature writes a new history that is different from the colonizer's 
version history. Colonizer assumes that colonization has no culture and does not contribute to human progress. Colonial history has made the colonizer a hero, a saviour who saves everyone from ignorance and darkness. Postcolonial writers write history from a different point of view and show that history is a perspective. They believe that there is no real history. Postcolonial writers are not only interested in the decolonization of political structures but also in mental and cultural decolonization which frees their mentality from the structures and philosophies of colonialism (Said: 1978).

Postcolonial literature is not only against and criticizing colonial powers but also against corruption which betrayed the dreams of newly independent states. Postcolonial literature also presenting a narrative of the diversity of cultural identities, and showing love for indigenous cultures and their own cultural identities, and breaking down stereotypes. Postcolonial literary works challenge the stereotypes used to justify colonialization. Colonized people are given a lower stigma or stereotype than the colonizer as justification for the colonizer's superiority (Said:1978).

Postcolonialism theorist, Edward Said, in his book Orientalism explores and questions artificial boundaries, stereotypical boundaries that are depicted between West and East. Said saw how the colonizer saw himself as "Us" and colonized as "Other" (Said, 1978). Meanwhile, Homi K. Bhabha, in his book The Location of Culture and Nation and Narration (1994) focuses on politics, emotions and values that exist in the space between Colonizer and Colonized.

\subsection{Homi K. Bhabha's Post Colonialism: Hybridity and Ambivalence}

This research examines Abe Tomoji's Shi no Hana with the theoretical framework of postcolonialism from Homi K. Bhabha. In contrast to Said, who uses the framework of 'binary opposition' to see the colonial and colonized relationship, Homi
$\mathrm{K}$. Bhabha sees that the colonial and colonized relationship is not just about "us" versus "other". However, this relationship produces a third space that allows interaction between the colonizer and the colonized. Produces something new, which is hybrid and ambivalent.

Homi K. Bhabha is a cultural studies expert who focuses on colonialism and postcolonialism theories. The study of oppression, traumatic colonial feelings, and the impact of other influential factors that produce other cultures, creeds, customs, and civilizations are heavily influenced by Foucault, Edward W Said, Jacques Derrida, Lacan and Sartre. His theoretical postulate is based on the primary but experimental concepts of liminality, hybridity, mimicry and ambivalence which are stimulants of cultural productivity".

The critical concept of Bhabha is expressed in four words: liminal, hybrid, mimicry and ambivalent. The concept "describes how the colonized people have resisted the colonial power. Instead of seeing colonialism as something locked in the past, Bhabha shows how the history and culture of colonialism have continued to" disturb "until recently. Bhabha's view made us change the understanding of cross-cultural relations. The power of the dominant nation and the dominant idea is never as complete as it seems because it is always marked by anxiety about the possibility of resistance from those who are dominated. To show this restlessness, Bhabha looks back on history colonialism (Hudart, 2005:1).

The concept of 'Location of Culture' for Bhabha is the result of the spread of the dominant culture or the seeds of culture and the proliferation, substitution or imprint of the dominant culture. As a deconstructionist, Bhabha defined culture as the product of another culture. In his essay "Dissemination: time, narrative, and the margin of the modern nation" which is contained in The Location of Culture, Bhabha offers the idea of a vital symbolic and affective source of cultural identity'. In the essay, 
IZUMI, Volume 9 No 2, 2020, [Page | 179]

e-ISSN: 2502-3535, p-ISSN: 2338-249X

Available online at: http://ejournal.undip.ac.id/index.php/izumi

Bhabha said that the ambivalence of a nation is a narrative strategy used as a power tool. According to Bhabha, ambivalence refers to the mental or social or cultural state or behaviour of people which includes both positive and negative aspects of anything. Bhabha explains the idea of ambivalence in the form of culture or culture itself from a nonconstructive point of view. Changes in the cultural system that occur after the colonial period of a country will always be ambivalent and hybrid. The hybridity of each culture creates ambivalent conditions (Bhabha, 1994).

\section{Result and Discussion}

\subsection{Depiction of Characters in Shi no Hana}

In Shi no Hana, Western characters are represented by Mr Van Den Brik, a Dutchman, Mr K a Danish, a Dutch scientist who was arrested, a Dutch woman whose husband was in prison, Mrs W, a woman with frangipani flowers embedded in her chest and others. Meanwhile, Eastern figures were represented by Japanese figures, namely Hinobe and Kibi, as well as Malay figures and local people.

Hinobe, a member of the Japanese propaganda force, is described as weak and in poor health.

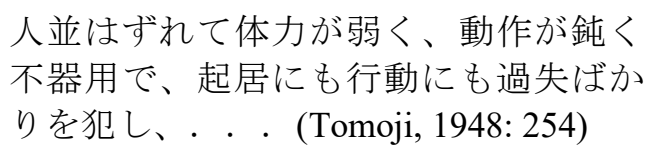

I am being fragile in physical strength, sluggish in movement, and clumsy...

$\mathrm{He}$ is also described as a soldier who does not obey military rules and cannot live in groups.

また船の底に乗せられて海を渡り、亜 熱帯の基地で待ったりしている時には、 いつも病気がちであり、その壁に放縦 で酒に耽って軍記に従わず、他人には 多くを望みながら自分は少しのことに
も腹を立て、到底団体生活はできめ奴 だと、まわりから匙を投げられた形だ ったのだが、. . . (Tomoji, 1948: 254)

When I am on the bottom of a ship, crossing the sea, waiting at a subtropical base, I am always sick. I was angry with myself, immersed myself in alcohol and disobeyed military rules. I got angry at small things while expecting a lot of other people, and those around me avoided me for not being able to live a group life at all. Though it is....

However, according to Dr K Hinobe is described as a kind person.

君のことを知っているです。一君が
僕の友人のオランダ人達、つまりこの
島の科学者達について心配しくれた
ことを。—君はそのためにこんな病
気になったにちがいないと思う。

(Tomoji, 1948: 266)

I know you -You worried about my friends, the Dutch, the scientists on this island. - I think you must have had this illness because of that

Even so, Hinobe also felt doubtful when Dr K said that he was a person who was willing to fight for scientists to suffer illness. Instead, he feels he is a hypocrite based on the following quote:

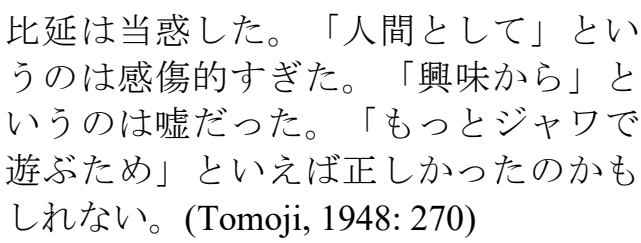

Hinobe felt embarrassed. "As a human being" is too sentimental. "Being interested" is a lie. Was it true that he felt that for humanitarian reasons or was it just because he wanted to stay longer in Java?

Mr Van Den Brik is a Dutchman who lives in the farm and garden around the hotel with his wife and children. Physically, Van Den Brink is narrated as follows: 
IZUMI, Volume 9 No 2, 2020, [Page | 180]

e-ISSN: 2502-3535, p-ISSN: 2338-249X

Available online at: http://ejournal.undip.ac.id/index.php/izumi

すると紺のオウワロウルをつけた灰白

の髮とつややかな顔色をした初老の男 が牧舎から歩いてきて、比延の後の方 で牧草の手入をしていたインドネシャ 人に何か巧みなマライ語でいいつけて いたが、それがすむと、比延の方に近 づいて。。(Tomoji, 1948: 259)

Then, an older man with dark grey hair and shiny complexion wearing navy blue owaloul walked out of the barn, and somehow skilful. He spoke fluently with an Indonesian grassman in Malay, then walked over to Hinobe.

Mr Van Den Brink was described as different from the Dutch in general.

$$
\begin{aligned}
& \text { 少くとも彼の待っているほう冒険心、 } \\
& \text { 意志力、勤勉、そぼくさ、快活さなど } \\
& \text { は、比延が今まで触れてみた多くの才 } \\
& \text { ランダ人にはほとんど見られぬものだ } \\
& \text { った。(Tomoji, 1948: } 261)
\end{aligned}
$$

At least his aspirational, willingness, diligence, sobriety, and cheerfulness were almost unheard of in the many Dutch people that Hinobe had ever touched.

Dutch scientists who were captured by the Japanese army are described as $\mathrm{Mr} \mathrm{A}$ and $\mathrm{Mr} \mathrm{B}$;

「動物学者のAは?」

「西ジャワに六匹だけ残っている犀の 世話をしていた老人さ。保護区域に、

一週に一度餌を持って犀の見舞いに行

っていた男さ。君たちが占領してから もしばらくは続けていたが、まもなく 捕らえられたときいた。」(Tomoji, 1948: 269)

"How about Mr A, the zoologist?"

"An old man who looks after the only six rhinos in West Java. He is protected to visit the lions once a week. After the Japanese occupied, I continued to protect him, but I heard that he was caught soon after."
「言語学者のBは?あれはむしろイン ドネシャ人に同情していて、自国和蘭 政府から睨まれていたが、優秀な学者 だった。」

「。. . 兵籍があって捕虜になったの

だ。・・」(Tomoji, 1948: 269)

"How about Mr B, the linguist? He was somewhat sympathetic to the Indonesians and was under suspicion by his government, but he was an excellent scholar. "

"....... He was arrested for being blacklisted by the military ..."

Edward Said's Orientalism theory describes West and East with the logic of binary opposition. The West is represented by countries in Europe and America, while countries in Asia and Africa represent the East. If the West is described as superior, then the East is inferior. If the West were colonizers, the East was colonized. However, from the description of the figures above, it can be seen that the dichotomy between the West and East is not so apparent.

Hinobe, who represents the East in the text, is not depicted as an inferior figure because he is a member of the Japanese propaganda force. However, instead of being depicted as a superior figure, Hinobe is described as physically weak. On the other hand, Western figures such as $\mathrm{Mr} \mathrm{A}$ and $\mathrm{Mr}$ $\mathrm{B}$ were not depicted as superior figures, but as prisoners captured by the Japanese army. Mr Van Den Brink is described as a Western figure who is fluent in Malay. This depiction shows the cultural interaction between the West and the East in the text.

The depiction of the figures above shows that the concepts of West and East, superior and inferior, here are ambivalent. If Said in his book Orientalism (1978) considers West and East imaginary geography, Homi K. Bhabha sees that the relationship between West and East produces hybridity and ambivalence. The values inherent in West and East in postcolonialism theory here are not sufficiently understood by the logic of binary opposition a la Said. 
However, they are understood as mutually influencing, resulting in hybridity between West and East.

\subsection{The interaction between "colonizer" and "colonized."}

In this research, Western characters are represented by $\mathrm{Mr}$ Van Den Brink a Dutchman, Mr K, a danish, the Dutch scientists who were arrested (Mr A, Mr B and $\mathrm{Mr} \mathrm{C}$ ), and Mr B's wife. Dutch woman whose husband was in prison, Mrs $\mathrm{W}$, a woman with frangipani flowers embedded in her chest and others. Meanwhile, Eastern figures were represented by Japanese figures, namely Hinobe and Kibi, as well as Malay figures and local people.

However, the categorization of West and East in the Shi no Hana text is not identical with colonizer and colonized. In Shi no Hana, West does not always occupy the colonizer category; likewise, East is not always colonized. Based on the space and time setting of the story in the text, the Japanese (East) occupy a position as the colonizer or the superior. In contrast, the Dutch (West) occupy the position as the colonized or inferior party. On the other hand, the Malays and local people (East) also occupy the position as colonized.

\subsubsection{The interaction between "colo- nizer" and "colonized" in the depiction of characters}

The interaction between colonizer and colonized appears in Hinobe's depiction. The Hinobe character is told in a positive tone as a kind, compassionate and humanist person. Hinobe's kindness is shown through the interaction between Hinobe and the wife of a Dutch scientist. At the beginning of the Japanese occupation, the Japanese army in Batavia arrested all Dutch males over the age of 17 , including scientists. Although Hinobe was a member of the Japanese propaganda force, he was empathetic and tried to help the wife of a Dutch scientist who was captured by Japanese soldiers. As a member of the propaganda force,
Hinobe should not have that kind of empathy. Hinobe's reason for helping the Dutch linguist's wife was based on a feeling of gratitude for the Dutch contribution in entering Western sciences into Japan during the Sakoku period.

•・・、捕らえられている言語学者のB道の角
土の、細君に出会ったが、赤ン坊をこ
めて五人の子供を持った彼女は、その
前夜に家を接収されたので、頼るべき
知人の家を探しながら街を歩いていた
のだ。ゆるされることととも思われな
かったが、比延はいくらかの軍票金を
あたえたが、それ以上に何も助けるこ
とはできなかった。(Tomoji, 1948: 267)

Just a few days earlier, he had met Mr B's wife, a linguist. Her husband was arrested. The woman walked around the city with her five children, including a baby. He looked for an acquaintance's house to get help because his house was confiscated the night before. With tears in her eyes, the woman wandered. Holding an empty stomach, she continued to walk through the city, which was shining with the scorching sun. Without thinking that his boss would not forgive his actions, Hinobe gave away all of his money. Hinobe could not help more than that....

比延は時々、江戸時代に日本がオラン ダの学問の恩恵を受けたことを思い出 し、この皮肉な歴史の転変におどろく ことがあった。(Tomoji, 1948: 267)

Hinobe is sometimes reminded of history when Japan received the advantage of knowledge from the Dutch during the Edo period. There was irony.

As a member of the Japanese propaganda force, Hinobe was in the superior position, while the woman, the wife of the Dutch scientist, was in an inferior position. Narrated, in the text that the Dutch scientist's wife roamed with her children because Japanese soldiers imprisoned her husband. 
IZUMI, Volume 9 No 2, 2020, [Page | 182]

e-ISSN: 2502-3535, p-ISSN: 2338-249X

Available online at: http://ejournal.undip.ac.id/index.php/izumi

At that time, the Japanese soldiers disarmed the defeated Dutch soldiers and arrested their scientists. Hinobe, as a member of the propaganda force, was part of the Japanese army who arrested the scientists. However, Hinobe still remembers the Dutch who contributed to bringing Western knowledge to Japan during the Sakoku era, so he was kind enough to help this poor Dutch woman. It can be seen that although Hinobe was a member of the Japanese propaganda force who was in the position of the colonizer, he felt inferior when he remembered the Dutch services to Japan in the past. The East, which occupies the colonizer position here is not depicted as being superior to the West, which occupies the colonized position. On the other hand, the West which occupies the position as colonized is described as in the quotation below;

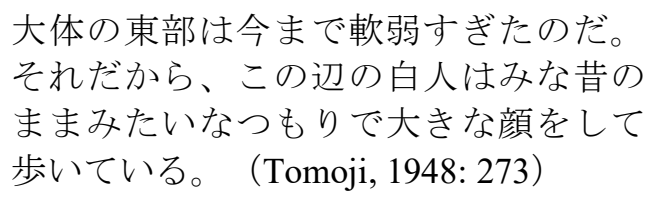

The eastern (Java) has been too weak to date. Therefore, all the white people around here walked over as arrogantly as they used to be.

Narrated above that because the Japanese occupation army was weak in East Java, the white people there were still superior. Unlike postcolonialism in Said's theory, which defines the West as the colonizer and superior and the East as the colonialized and inferior, in the text narrated that the West and colonialized do not always occupy colonizer is not always East. Likewise, the colonizer is not always superior and colonialized is not always inferior. Shi no Hana narrates East as the colonizer and West as the colonized. It can be seen that the concepts of East and West as well as colonizer and colonized are hybrid, and the relationship between colonizer and colonized here is ambivalent.

\subsubsection{The interaction between "colo- nizer" and "colonized" appears in the settings and events}

The interaction between colonizer and colonized, which is seen in the relationship between the character and the setting, appears through Hinobe's depiction of space. In the text, it is narrated that Hinobe was in the city of Malang to rest because of a lung disease he was suffering. The city of Malang had a cold climate. It reminds Hinobe of Japan. He compared the place he had lived in Japan with Selekta, a place in Malang, East Java. Japan, which in this case occupies a position as a colonizer, clearly has a different natural condition from Malang (Indonesia) which occupies a position as colonized. However, Hinobe feels it is a similarity, so as if he felt he was in the same space. Hinobe's life experience for many years in Japan and her experience while living in Malang led the interaction between colonizer and colonized elements exist in Hinobe's mind.

The interaction between colonizer and colonized, which is seen in the relationship between the characters and events appears in the events experienced by Kibi and Hinobe. A small event such as when Kibi ordered a hotel servant to wrap the rest of the sandwich (Shi no Hana: p. 253). The unfinished culture of wrapping food is common in Indonesia. In this snippet of events, Kibi told the hotel servant to wrap the sandwich that Hinobe did not finish eating. They could just leave the inexhaustible sandwich on the table. The time setting of this incident was during the Japanese occupation of Indonesia. Leaving food was probably a taboo thing at that time considering the condition of the Indonesian people who in history books are always described as suffering and lack of food. Here, although Hinobe and Kibi were the colonizers, they feel the suffering of Indonesians who were in the colonized position.

In the text, Dr K does not like Hinobe. As Hinobe heard from the hotel maid, the cause of Dr K against Hinobe is Dr K 
had received unpleasant treatment from Japanese soldiers (Shi no Hana: 258). The experience then made $\mathrm{Dr} \mathrm{K}$ is disabled. Hearing this, Hinobe, a member of the Japanese propaganda force, who occupied the position of the colonizer, did not necessarily defend the Japanese army. Hinobe's way of thinking here is not dichotomous and impartial. Hinobe was very humanistic and thought that the problem was the language barrier. In Hinobe's view, both sides had mistakes. Hinobe admitted that what the Japanese soldiers did was wrong. However, Dr K, who has his tension and prestige, was also at fault in this incident. This event demonstrates the complexity of the relationship between colonizer and colonized in the text.

The interaction between colonizer and colonized is also evident from the following events;

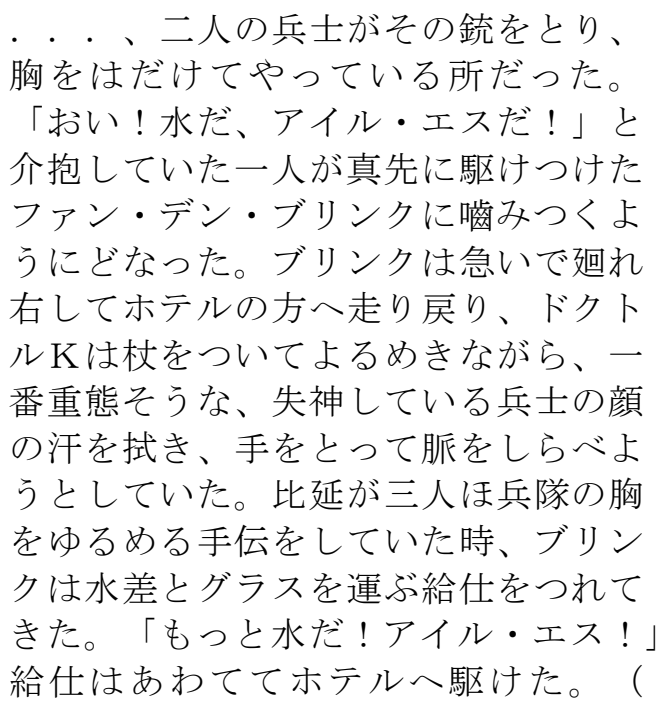

Tomoji, 1948: 264)

. . . Two soldiers were picking up the gun and bare their chests. "Hey! Water, cold water!" The one who was hugging the soldier screamed at Van Den Brink, who rushed to the front. Brink hurriedly turned to the right and ran back toward the hotel, and Dr $\mathrm{K}$ came unsteadily on his wooden stick. He wiped the sweat of the almost fainting soldier's face and took his hand to check for a pulse when Hinobe helps the three soldiers to loosen their breathing, Brink orders the servants to bring glasses and jugs. "More water! cold water!" The servant rushed to the hotel.

This event illustrates cooperation and humanity in helping the Japanese soldier who collapsed. Hinobe the Japanese, Van Den Brink the Dutch, and Mr K the Danish worked for hand in hand to try to help the soldiers who collapsed without thinking about their country of origin. Without thinking about colonizer or colonized they are. The relationship between colonizer and colonizer here is not represented by the logic of the binary opposition where one oppresses the other. As in Bhabha's theory, the relationship between colonizer and colonized allows cultural interactions to influence each other. In this case, West and East, colonizer and colonized become hybrid and ambivalent.

\section{Conclusion}

Ambivalence and hybridity are found in the depiction of the figures in the text. Unlike Said's Orientalism theory, which defines the West as the colonizer, the superior and the East as the colonialized, the inferior, in the text narrated that the West and colonialized do not always occupy colonizer is not always East. Likewise, the colonizer is not always superior and colonialized is not always inferior. Shi no Hana narrates East as the colonizer and West as the colonized. It can be seen that the concepts of East and West as well as colonizer and colonized are hybrid, and the relationship between colonizer and colonized here is ambivalent. If Said's Orientalism considers West and East imaginary geography, Homi K. Bhabha sees that the relationship between West and East produces hybridity and ambivalence. The values inherent in West and East in Bhabha's postcolonialism theory here are not sufficiently understood by the logic of binary opposition a la Said. However, they are understood as mutually influencing, 
IZUMI, Volume 9 No 2, 2020, [Page | 184]

e-ISSN: 2502-3535, p-ISSN: 2338-249X

Available online at: http://ejournal.undip.ac.id/index.php/izumi

resulting in hybridity between West and East.

Hinobe's role in this text depicts the figure of the author Abe Tomoji, a writer who was sent to the south as a member of the propaganda army. Hinobe's action of recording Dutch scientists who were arrested by the Japanese made the colonizer and colonized positions become complex. This seemed to describe Japan in its interactions with Western and Eastern nations. Japan, although geographically in the Asian region, feels superior when dealing with other Asian countries because Japan is more developed economically and technologically. However, when dealing with European countries, Japan became inferior because the development of the Japanese nation could not be separated from the West. It gives rise to an ambiguous and complex Japanese character.

Noriko Imazawa (1993:393-394), the translator of Said's Orientalism in Japanese in her afterword claims that Japan has a significant position in the structure of Orientalism. Geographically and culturally, Japan, being a part of the non-Western world, no doubt belongs to the colonized or the inferior. Modern Japan, however, practised Western-style imperialism when it rules its neighbouring colonies. So, Japan became the East that has a position as the colonizer. Japan's position here is contradictory and ambivalent. Homi K. Bhabha (1990:292) considers the ambivalence of the nation as a narrative strategy and an apparatus of power.

In the context of the Japanese occupation in Indonesia, the ambivalent was used by Japan as the apparatus of power to colonize. Through the slogans "Nippon Leader of Asia ", "Nippon Protector of Asia" and "Nippon Light of Asia", Japan, as a fellow Asian, claim itself an old brother who protects Asia from colonialism by the West. Nevertheless, Japan acted as a colonizer for its brother.

\section{Acknowledgements}

This research was generously supported by the Department of Languages and Literatures Faculty of Cultural Sciences Universitas Gadjah Mada Yogyakarta.

\section{References}

Buruma, Ian. (2003). Inventing Japan. New York: Modern Library

Beasley, W.G. (2003). Pengalaman Jepang: Sejarah Singkat Jepang. Jakarta: Yayasan Obor Indonesia.

Bethvine, Y. (2005). Representasi Shi dan Hana pada Hinobe dalam Shi no Hana Karya Abe Tomoji. Tesis (tidak diterbitkan) Pascasarjana UNESA

Bhabha, Homi. K. (1990). Nation and Narration. London: Routledge

Bhabha, Homi. K. (1994). The Location of Culture. London Routlede

Fransiska, Gita. (2014). Wacana Orientalisme Dalam Novel Shi no Hana Karya Abe Tomoji. Tesis (tidak diterbitkan). Kajian Wilayah Jepang UI. http://lib.ui.ac.id/detail.jsp?id=20390419

Handayani, Irvina Restu. (2018). Humanisme in Shi no Hana and Tsumi no Hi by Abe Tomoji (Oriental-ism Study). Jurnal Penelitian Humaniora Vol 23 No. 2 Oktober 2018 https://journal.uny.ac.id/index.php/humaniora/article/view/23937 . Accesed: $14 / 02 / 2018$

Harada, Yoko. (2006). "The Occident in the Orient or the Orient in the Occident?: Reception of Said's Orientalism in Japan”. University of Wollongong Research Online Faculty of Arts - Papers (Archive) Faculty of Arts, Social 
IZUMI, Volume 9 No 2, 2020, [Page | 185] e-ISSN: 2502-3535, p-ISSN: 2338-249X

Available online at: http://ejournal.undip.ac.id/index.php/izumi

Sciences \& Humanities 1-1-2006 The occident in the orient or the orient in the occident?: reception of Said's Orientalism in Japan Yoko Harada University of Wollongong, yh99@uow.edu.au. Accessed: 19/06/ 2018

Hudart, David (2005). Homi K. Bhaba. Psychology Press.

Huffman, James L. (2017). Japan and Imperialism, 1853-1945. MI USA: AAS Inc.

Kimura Kazuaki. (2009). Kembang Kamboja (Prolog), dalam Abe Tomoji (2009). Kembang Kamboja. Jakarta: Iluni KWJ Press.

Marcus, Marvin (2015). Japanese Literature from Murasaki to Murakami. MI USA: AAS Inc

Minear, Richard H. (1980). Orientalism and the Study of Japan. The Journal of Asian Studies Vol 39 Issue 3 May 1980 , pp. 507-517 https://www.cambridge.org/core/journals/journal-ofasian-studies/article/ orientalism-andthe-study-of-japan/E7533D730E411336C7730C5D 0D3A7AA9. Accessed: 05/07/2018

Nishihara, Daisuke. (2005). "Said, Orientalism and Japan". Journal of Comparative Poetic No. 25, 5002 Edward Said and Critical Decolonization p. 241-253. https://www.jstor.org/stable/4047459?seq=1 Accessed: 26/01/2017

Noriko, Imazawa. (1993). "Yakusha Atogaki (Afterword)," Orientalism vol. 2. Tokyo: Heibonsha, p 393-394.

Said, Edward W. (1978). Orientalism. NY: Pantheon Books.
Tomoji, Abe (2009). Kembang Kamboja. Jakarta: Iluni KWJ Press.

Tomoji, Abe. (1948). Shi no Hana. Tokyo: Shinbungeisha 